the Thaw, as well as Gulag returnees. The framework of de-Stalinization almost inevitably highlights these particular areas of Soviet historical experience of this period, while many others - such as history of the working class, Indigenous people or the military-remain in the shadows.

Alexey Golubev

University of Toronto

\title{
Shawna Ferris, Street Sex Work and Canadian Cities: Resisting a Dangerous Order, (Edmonton: The University of Alberta Press, 2015). 272pp. Paperback
} $\$ 34.95$.

In the book adaptation of her dissertation research, Shawna Ferris, an Assistant Professor in the Women's and Gender Studies Program at the University of Manitoba, examines "the effects of transnational free-market economics, ongoing urbanization, and growing concerns regarding home and homeland security on contemporary representations of and responses to street-involved sex work in Canada" (xv). Her selected sources for analysis reflect not only her humanities background (e.g., she offers close readings of two autobiographical novels exploring Indigenous women's experiences in street sex-work) but also her sensitization to multidisciplinary approaches (e.g., she examines news media, anti-prostitution activist and policing sources, and sex-worker activist texts). As a result, her book offers compelling insights into the competing discourses about, and reactions to, sex-work in Canadian cities that will appeal to readers across the social sciences and humanities in addition to the interdisciplinary field of women's and gender studies.

Ferris couches her analyses of Canadian urban street sex-work in a broader critique of the detrimental influence of "globalization's sanitizing neoliberal and neoconservative agendas in Canadian urban centres ... [on] Canada's current reputation as a liberal democracy concerned with the rights of all its citizens" (xx). She argues that global capitalism has compelled Canada to initiate "urban cleanup projects" aimed at attracting businesses to locate in their cities and tourists to visit (xx). As a result, sex-work, once "synecdochic" with the city, has been deemed an "urban menace" to be eradicated as to not deter businesses and consumers from flocking to Canadian cities (3, xxi). Through this theoretical lens, she explores how dominant representations of and reactions to street sex-work serve this end game and concomitantly fuel a "necropolitics, or privatization of the right to secure, police, or take deadly action against private citizens [e.g., street sex-workers] who are considered "disposable" that contradicts the liberal democratic ideology professed to characterize Canadian sociopolitics (xv-xvi). Within this overarching framework grounded in class-structural critiques, she also problematizes the disproportionate number of, and abject violence against, Aboriginal women among street sex-workers. Ferris traces this overrepresentation to the intersecting legacies and continuing 
impact of colonization, misogyny, and systemic racism. Guided by this overarching critical framework, Ferris's four substantive chapters are divided into two explorations: discourses offered by non-sex-workers that support this necropolitical global-capitalist agenda (Chapters one and two), and those offered by sex-workers that challenge it (Chapters three and four).

In Chapter one, Ferris examines media coverage of 65 women, "more than half of whom were Aboriginal, and many of whom were street-involved [sexworkers]," who disappeared from the impoverished Downtown Eastside neighborhood in Vancouver between the years 1975-2001, several of whose murdered bodies were later discovered (1). She concludes that the prevailing media representation of these missing women aligns with the necropolitical discourse that the victimized women were deserving of their fate, particularly due to their largely indigenous status. Reminiscent of sociologists Joel Best and Donileen Loseke who explore the social construction of social problems via rhetorical analyses, Ferris argues that these "stigmatizing narratives" proffered by the media "manufacture a culture of fear," wherein:

Private citizens are encouraged to fear not the social circumstances that lead to survival sex work or drug addiction, and violent death, but the repercussions of these women's supposedly irresponsible choices and lies. Under this manufactured culture of fear the murdered women themselves become the threat, not the victims of a particularly heinous form of violence (20).

Ferris continues this line of argument in the first section of Chapter two, focusing particularly on the "problematic and stigma-laden" tropes of the "missing woman" and "the lone streetwalker" which pervade the media and perpetuate a stereotypical image of street sex-workers that again constructs them as victims of their own personal shortcomings rather than broader socio-structural inequities based in class, gender, and race (43). She then turns her analytical eye to anti-prostitution neighbourhood activists and police responses, concluding that a "not in my back yard" discourse pervades their representations and reactions to street sex-work in their environs. Likewise, she argues that the focus on criminalization amongst anti-prostitution activists and policing, versus recognizing sex work as perhaps the only viable money stream for many street-level sex-workers, negates women's personal agency in participating in this line of work as well as forces them to work in even more "solitary and dangerous" conditions (74). Ferris connects her analyses of these dominant anti-sex work discourses back to her critique of the global-capitalist agenda, arguing that this apportionment of "legitimate" citizens and "socalled others," which serves this necropolitical agenda, 
signifies a general and alarming disavowal on the part of the Canadian liberal democratic nation-state of its responsibilities to uphold and protect the social, civic, and economic freedoms - as well as the basic human rights_-of all of its citizens [emphases in original]" (81-82).

Ferris devotes her final two substantive chapters to exploring sex-workers' own voices, which, not surprisingly, she finds in sharp contrast to those in her previous analyses. She first thoroughly investigates the websites of three sex worker activist groups: the Sex Workers Alliance of Vancouver (SWAV), Sex Professionals of Canada (SPOC) in Toronto, and Stella of Montreal. Ferris finds that when sexworker activists tell their own stories, they counter the dominant discourse that constructs them as "placeless, voiceless, and alone" (97). Instead, they present a picture of empowering community, alliances, and personal agency. Likewise, they argue for decriminalization of their work and offer solutions to their safety issues that recognize the legitimacy of their professional choice within a larger economic system that is largely stacked against them due to their race, gender, and class.

In Chapter four, Ferris returns to her humanities roots to explore the relative absence of Aboriginal women's voices in sex-worker activism via a close reading of two autobiographical novels with Aboriginal sex-worker protagonists: Maria Campbell's Halfbreed (1973) and Beatrice Culleton Mosionier's In Search of April Raintree (1984). Ferris takes to task the predominantly white sex work activists' sweeping claims that sex-workers largely exercise their own personal agency in choosing their profession, noting that "systemic racism and ongoing colonial violence" problematize the notion that Aboriginal women truly freely choose to participate in the sex work trade (144). Ferris argues that these authors via their novelistic portrayals root the overrepresentation of Aboriginal women in the sex trade and violence perpetrated against them "not [in] random inexplicable acts for which exceptional, culturally marginalized persons are responsible, but rather [in] inevitable expressions of the violent, racist, misogynistic cultural centre" (157).

In conclusion, Ferris presents compelling evidence of how the representations of and responses to sex-work in Canadian cities reflect a necropolitical global-capitalist agenda that contradicts the liberal democratic ideals that the Canadian nation-state purports to uphold. Likewise, she offers a nuanced and complex analysis of how the experiences of Canadian urban street sex-workers and the representations of them by others must be understood from the intersections of class, gender, and race. Reflecting her sensitization to feminist action research, she fittingly concludes her book with this call to arms to resist this imposition of "dangerous order" in Canadian cities:

Stigma-inflected, classed, and racialized violence, as well as the anti-prostitution police and private citizen-driven initiatives this 
violence has provoked in Canadian inner cities, reify a decidedly anti-feminist position: that certain women deserve, even invite the violence to which they are subjected. Furthermore, we must find means to counter decidedly anti-feminist public responses to mass/serial murder cases that imply that any poor womanand particularly any Indigenous woman-who stands on an urban street and offers sexual services to passersby in exchange for money or drugs is essentially suicidal and thus shares responsibility for any violence-misogynist, racist, classist, or otherwise- to which she is subjected (178).

Mandy Swygart-Hobaugh Georgia State University

\section{Holly M. Karibo, Sin City North: Sex, Drugs, and Citizenship in the De- troit-Windsor Borderland (Chapel Hill: University of North Carolina Press, 2015). 226 pp. Paperback $\$ 29.95$.}

This short and impressively well-written book explores sex, drugs, and citizenship in the Detroit-Windsor borderland between the 1920s and 1967 (the year of the Detroit race riot). Situated in the strong tradition of borderlands scholarship, the book takes as its focus the less studied borderland between the United States and Canada. Karibo argues that borderlands have often been conceived as "meeting places" where people from different cultures came together. The Canada/US border is marked more by similarity than difference, and yet the border still matters: while this border was crossed frequently for trade, work and pleasure it was also upheld against the vice that was perceived to exist on both sides.

The book starts with the opening of the Ambassador Bridge between the two countries in 1929. The bridge and tunnel eliminated the necessity for the short ferry rides that had previously taken people from Windsor to Detroit and vice versa. Karibo explains that the bridge (which could handle as many as 4,000 cars/hour) exemplified the growing connections between the two countries for trade and travel, but that the bridge's well-regulated border inspection process also reified a border that had once been policed fairly informally. I was surprised to learn exactly how many people in the Canadian border cities worked in Michigan: Karibo reveals that by $1927,15,000$ of the 25,334 employed residents of the Canadian border cities actually worked on the other side of the border (19).

The different liquor laws in the two countries helped to create the region's illicit economies. Ontario's experiment with prohibition was relatively short-lived and the province never forbad the production of alcohol. As a result, the DetroitWindsor border (or the Detroit-Windsor funnel) became a major site for smuggling liquor from Canada to the US. After Ontario repealed prohibition in 1927 and 